\title{
ОСОБИСТІСНО-РОЛЬОВЕ МОДЕЛЮВАННЯ МОЛОДДЮ АКТИВНОЇ СОЦІАЛЬНОЇ ПОВЕДІНКИ
}

\begin{abstract}
Обгрунтовано й концептуалізовано особистісно-рольове моделювання як явище рольової взаємодії, що полягає у виборі та освоєнні структурно-функціональної “канви” дій та плануванні подальшої взаємодії. Наголошується на значенні саморегуляції особистості та іiі суб'єктних властивостей в активній соціальній поведінці молоді, в основі якої лежить здатність до особистісно-рольового моделювання соціальних і міжособових ролей, пов'язаних 3 роллю громадянина. Особистіснорольове моделювання розглядається як ресурс активізації соціальної поведінки молодих людей, йому відводиться роль психологічного механізму освоєння лояльних та успішних ролей як способів дії в різних ситуаціях соціальної взаємодії. Звертається увага на те, що психологічні технології особистісно-рольового моделювання і практичні емпіричні напрацювання можуть використовуватися в психологічному супроводі i для формування активної соціальної поведінки молодих людей у процесі політичної участі. У разі підходу до громадської активності 3 позицій моделювання акцент робиться на утворенні внутрішніх особистісних детермінант, що зумовлюють таку поведінку, яка дає змогу переглянути та вдосконалити використовувані досі стимулятори активності молодих людей як членів громадянського суспільства.

Ключові слова: активна соціальна поведінка, політичні дії, рольова взаємодія, групова взаємодія, моделювання рольової поведінки, особистісно-рольове моделювання.
\end{abstract}

Постановка проблеми. Коли йдеться про активну соціальну поведінку молодих членів громадянського суспільства, яка має бути свідомою, добровільною, ініціативною та мотивованою, від учасників взаємодії очікують конкретних політичних дій соціально-політичного спрямування. Проте сучасна молодь здебільшого лише інформаційно присутня в суспільно-політичному просторі, ïi ж сподівання на зміни в державі, за нашими даними, не підпираються особистою готовністю здійснювати активні соціально-політичні дії. Більшість молодих людей зазвичай очікують активності від інших, займають рольову позицію “спостерігачів” і готові лише приєднуватися до активних. Сучасна молодь недостатньо обізнана щодо лояльних способів взаємодії з владою і знає в основному екстремальні форми політичної взаємодії, що призводить у звичних, “штатних” ситуаціях до низької активності або ситуативної бездіяльності. Підкреслимо, що пропонований підхід до політичної поведінки з позицій моделювання та використання можливостей саморегуляції ще не вичерпав свого потенціалу. Наразі структуру та вчинково-поведінковий зміст активної соціальної поведінки не можна вважати достатньо вивченими. 
Meта статmі: розглянути політичні дії як складові активної, ініціативної соціальної поведінки, яка породжує спільну діяльність у процесі соціальної взаємодії; презентувати авторську точку зору на особистісно-рольове моделювання активної соціальної поведінки як механізм вибору поведінкового репертуару.

Аналіз останніх досліджень $і$ публікащій. У цій статті нам би хотілося наголосити на особистісно-рольовому моделюванні як психологічному механізмі освоєння лояльних та успішних ролей - певних способів дії в ситуаціях соціально-політичної взаємодії. Якщо достатньої кількості зразків політичної поведінки, які б відповідали нормам демократичної політичної культури, немає, то продуктивним може бути, як зазначає I. В. Жадан, застосування в суспільствознавчій освіті технологій моделювання [5].

За Ю. В. Криловим, модель зазвичай розуміють як уявну або реальну систему, яка відображає або відтворює комплекс суттєвих властивостей та параметрів об'єкта і здатна заміщати його в процесі пізнання. Терміном “моделювання” позначають створення певного фрагмента соціальної реальності або концептуально-теоретичного утворення [8]. Почуттєво-наочною основою моделювання зазвичай стають метафори; досить часто може використовуватися інтуїтивне моделювання (зокрема, життєвий досвід людини можна розглядати як інтуїтивну модель міжособових взаємин).

Ми виходили 3 того, що людині властиво самій моделювати свою поведінку, а одним із продуктів такого моделювання $\epsilon$ ролі. Моделювання можна розглядати як штучне створення наперед заданих ситуацій, прийняття рольових позицій та взаємодію 3 виконавцями комплементарних ролей. Цілеспрямоване моделювання можна відпрацьовувати в тренінговій групі, де відбувається вплив групових феноменів. На всіх рівнях моделювання будуть позначатися особистісно-рольові закономірності. Також людині можна допомогти вдосконалити моделювання і планування власної поведінки за рахунок саморегуляції.

Поведінка особистості в суспільстві реалізується за допомогою ролей, пов'язаних 3 певним соціальним контекстом та оточенням (П. П. Горностай, Є. Мелібруда, Т. Парсонс). У ролях реалізується суспільно вироблена програма дій людини в певних умовах та закріплюються стійкі способи поведінки в суспільстві, які залежать від статусу особистості в групі, а також у системі соціальних і міжособових стосунків. Роль як така відображає систему відносин, перелік і послідовність дій у певних життєвих обставинах та реалізує рольову ідентичність особистості. Соціальні санкції, приписи, правила й очікування окреслюють соціальну визначеність рольових моделей особистості та надають молодій людині права, уособлені в ролі. Поведінководіяльнісне втілення рольової моделі поведінки співвідноситься з певними зразками, соціальними нормами і стандартами. Виконуючи роль, 
особистість враховує можливі зміни ситуації, наслідки рольової поведінки та можливість досягти бажаного результату. Виконання ролей пов'язує та узгоджує поведінку учасників групи одне щодо одного, значущі виконувані функції закріплюються в комплексі ролей у вигляді рольового репертуару особистості.

Рольову поведінку можна розглядати як особистісний феномен, що знаходить прояв у рольовій ідентичності та рольовій Я-концепції [3]. Репертуар психологічних ролей особистості формується в контексті історії ії життя, структури життєвого світу, системи особистісних цінностей. Ролі можна інтерпретувати як одну 3 форм функціонування особистості серед інших людей у групі. Прийняття ролі передбачає взаємодію з іншою особистістю та розуміння ії внутрішнього світу. Однією із сторін цього процесу є феномен “дзеркального Я” як представлення себе кимось іншим, хто дивиться на вас збоку [4]. У символічному інтеракціонізмі Дж. Міда поняття “конструювання соціальної реальності" є фактично описом практики моделювання, відповідно до якої люди поводяться щодо інших людей залежно від значень, якими вони їх наділяють. Таке значення виникає внаслідок соціальної взаємодії людей (Г. Блумер), а власне комунікація відбувається завдяки символам (Дж. Мід). Важливою стороною моделювання $є$ здатність побачити ролі “збоку” та виокремити значущі ознаки, що характеризують лінію поведінки. Виникає феномен особистісно-рольової взаємопредставленості, яка полягає в ціннісно-смисловій та рольовій узгодженості учасників взаємодії та проявляється в прагненні ідентифікуватися або відособитися. Рольове моделювання лежить в основі організації взаємодії в групі і має на меті, у тому числі, досягнення взаєморозуміння між членами цієї групи [6]. При цьому кожна роль набуває особистісного забарвлення, значущості, вирізняється стилем виконання.

$€$. Мелібруда зазначав, що в процесі спілкування людей формуються зразки і моделі поведінки, які згодом “входять усередину людини" [10]. Кожна особистість має психологічну, внутрішню модель ролі, що стає основою рольової саморегуляції та саморозвитку. Автор рольової теорії П. П. Горностай стверджує, що рольове трактування особистості більшою мірою відображає ії сутність, аніж, припустімо, теорії рис або факторні моделі особистості. Рольовий розвиток $є$ специфічним та важливим аспектом розвитку та становлення особистості як такої [3]. Засвоєння особистістю певних форм поведінки потенціює формування відповідних особистісних характеристик. Репертуар особистісно-рольових уявлень людини проявляється в ії міжособових стосунках, що відображено в теорії позиціонування Р. Гарре, теорії драматизму К. Бьорка та драматургічній теорії І. Гофмана.

Особистісні особливості активної соціальної поведінки знаходять свій вияв у тому, як діє конкретна людина залежно від ситуації, як 
вона інтерпретує дії і вчинки інших, чого очікує від майбутнього. На основі уявлень про себе суб'єкт формує ідентичність як самототожність та Я-образ як системне самоуявлення особистості, яке розвивається i формується у взаємодії з іншими людьми. Т. Парсонс розглядав роль як очікувану послідовність способів поведінки і виконуваних функцій або дій, які відповідають соціальному статусу людини, видаються доречними та реалізуються в даному соціальному контексті [12]. Важливим для нас $\epsilon$ те, що рольові функції реалізуються в конкретних діях і вчинках індивіда в процесі виконання ним ролей.

Політично спрямована поведінкова активність людини передбачає включення в суспільний простір через осмислення інформації про політичні події та співвідношення політичних сил, постановку та досягнення цілей у конкретних діях та діяннях на основі притаманних особі смислів. Соціально-політична поведінка особистості є комплексом вибіркових свідомих взаємопов'язаних дій, що здійснюються суб'єктом у груповій взаємодії. Політичні дії є багатоплановими, реалізуються у вигляді відкритої поведінки та дій і залежать від взаємодії з іншими учасниками та соціальними групами, від соціуму та соціально-політичної ситуації, які динамічно змінюються.

Активна соціальна поведінка здійснюється людиною із суб'єктних позицій у суспільному просторі і мотивована особистісним ставленням, означена виконуваними соціально значущими функціями та соціальною позицією суб'єкта цієї поведінки. Концепції поведінки розробляли 3 позицій теорії діяльності, суб'єктності та індивідуальності М. Я. Басов, М. І. Боришевський, О. М. Леонтьєв, С. Д. Максименко, В. С. Мерлін, С. Л. Рубінштейн та ін. Теорія діяльності дістала подальший розвиток у суб'єктно-вчинковому підході та теорії вчинку як комунікативного акту, що здійснюється між особистістю і матеріальним світом (В. А. Роменець, В. О. Татенко). Саме вчинкова комунікація, як зв'язок між особистістю і зовнішнім світом та ііі утвердження в матеріальному світі, передбачає особистісне виокремлення людини зі світу [11]. Суб'єктність як інтегральна якість особистості виявляється в ціннісносмисловій самоорганізації дій та усвідомленій саморегуляції і веде до зміни себе, своїх внутрішніх позицій і навколишньої дійсності внаслідок активно-перетворювальної діяльності (О. Г. Асмолов, О.В.Брушлинський, О. М. Леонтьєв, С. Л. Рубінштейн). На те, що психічні процеси людини базуються на моделюванні, звертали увагу в різних контекстах Г. О. Балл, Д. О. Леонтьєв, С. Д. Максименко та ін. Людській свідомості властива здатність до моделювання, яке виявляється в різних сферах життєдіяльності суб'єкта.

Вважаємо, що особистісно-рольове моделювання лежить в основі процесу взаємодії та відбувається на основі відображення в згорнутому вигляді психологічних комунікативних ролей як моделей поведінки, 
що стосуються очікуваної послідовності дій залежно від обставин 3 притаманним їм емоційно-мотиваційним супроводом. Отож ми розглядаємо моделювання активної соціальної поведінки як актуалізацію властивих людині рольових моделей, які складаються 3 мотивованих дій у певним чином інтерпретованій проблемній соціальній ситуації.

Суб'єкт активної соціальної поведінки є реальним носієм здатності до саморегуляції власного життя, діяльності та діянь. Він керується інтеріоризованими еталонами та зразками поведінки у формі принципів, норм, правил, переконань, ідеалів, прагнень. Генетико-моделювальний підхід висуває на перший план цілісну особистість, якій притаманна, за С. Д. Максименком, здатність до самомоделювання і саморозвитку [9]. Так, кожній людині властиво здійснювати саморегуляцію активної соціальної поведінки, а саме створювати в уяві, як вважає Г. О. Балл, “спонукальну цільову модель" [1] бажаного розвитку майбутніх подій, ситуацій та результатів. Активна соціальна пове-дінка узгоджується 3 потребами, цілями і бажаннями суб'єкта, на основі чого може формуватися рольова модель діяння в певній ситуації взаємодії.

Тут ми хотіли б звернути увагу передусім на дієву складову особистісно-рольового моделювання активної соціальної поведінки, беручи до уваги те, що активна соціальна поведінка складається 3 дій (О. М. Леонтьєв, О. М. Смирнов). Засобами дій можуть виступати, в тому числі, ролі, при цьому в процесі їх застосування суб'єкт оволодіває діями, перетворює їх на особисті, такі, що належать саме йому: власне, за допомогою соціальних ролей дії людей, зазначає Т. Парсонс, вписуються в соціальну систему. Кожна роль передбачає відповідність дій певним соціальним очікуванням, загальноприйнятим нормативним i ціннісним стереотипам. Завдяки ролі індивід інтегрується в структуру всієї соціальної системи в цілому [12].

Виклад основного матеріалу дослідження. Мотивованість $є$ важливим критерієм дій, що лежать в основі активної соціальної поведінки. Учасникам властиво раціонально пояснювати власне розуміння джерел поведінки, іiї причини, посилаючись на соціально прийнятні для них і референтної групи обставини, що спонукали до вибору тієї чи тієї дії. Лояльні дії активної соціальної поведінки зумовлюються, як показали результати проведеного нами дослідження, певними мотивами. За основною спрямованістю ці мотиви бувають інтрасуб'єктні, інтерсуб'єктні та соціальні [7]. Для того щоб встановити, які саме дії є найбільш мотивованими в активній соціальній поведінці молоді, ми застосували двовимірну модель, яка враховує політичні дії та мотивування. Види мотивування та перелік дій активної соціальної поведінки було відібрано на основі опитування експертів. Це 27 осіб віком 18-30 років. Основою доцільності тих чи інших дій у проведеному дослідженні стали мотивування, які спираються на функціональну відповідність та смисли соціальної поведінки, такі як прагнення до знань, до лідерства, 
до виконання громадянського обов'язку тощо. За процедурою непрямого шкалування досліджувані оцінювали за п'ятибальною шкалою перелік основних відібраних експертами політичних дій і діянь, що входять до моделей політичної поведінки, під кутом зору того, наскільки кожне із запропонованих мотивувань може спонукати до тієї чи іншої політичної дії. Таким чином політичні дії були проранговані учасниками залежно від ступеня їх вмотивованості. Коефіцієнт мотивованості дій вираховувався як середнє значення оцінок, які отримала та чи інша поведінкова модель. У дослідженні взяли участь 72 студенти київських ВНЗ. На основі емпіричних даних було визначено ієрархію, яка дає, власне, уявлення про структуру та значущість основних дій активної соціальної поведінки (табл.).

Таблиия

Найбільш умотивовані політичні дії в складі моделей активної соціально-політичної поведінки

\begin{tabular}{|c|c|c|}
\hline Моделі активної соціальної поведінки молоді & $\begin{array}{c}\text { Значення } \\
\text { середнього } \\
\text { коефіцієнта } \\
\text { мотивованості } \\
\end{array}$ & Ранг \\
\hline $\begin{array}{l}\text { Виступити на зборах і переконати людей щодо } \\
\text { правильності своїх політичних поглядів }\end{array}$ & 3,98 & 1,5 \\
\hline Вступити в політичну партію & 3,98 & 1,5 \\
\hline Брати участь у громадських заходах & 3,79 & 3 \\
\hline $\begin{array}{l}\text { Запропонувати свою кандидатуру для участі } \\
\text { в передвиборчій кампанії }\end{array}$ & 3,77 & 4 \\
\hline $\begin{array}{l}\text { Цілеспрямовано впливати на органи влади } \\
\text { шляхом написання звернень }\end{array}$ & 3,76 & 5 \\
\hline $\begin{array}{l}\text { Приєднатися до обговорення, коли друзі } \\
\text { обговорюють політичну ситуацію в країні }\end{array}$ & 3,64 & 6 \\
\hline $\begin{array}{l}\text { Брати участь у проведенні політичних } \\
\text { передвиборчих кампаній }\end{array}$ & 3,63 & 7,5 \\
\hline Прийти на мітинг & 3,63 & 7,5 \\
\hline Брати участь у політичних акціях & 3,58 & 9 \\
\hline Відстоювати свою точку зору & 3,56 & 10 \\
\hline $\begin{array}{l}\text { Організувати збирання коштів для підтримки } \\
\text { соціально незахищених громадян }\end{array}$ & 3,54 & 11 \\
\hline $\begin{array}{l}\text { Запропонувати способи вирішення конфлікту } \\
3 \text { адміністрацією }\end{array}$ & 3,53 & 12 \\
\hline $\begin{array}{l}\text { Запропонувати свою допомогу в організації } \\
\text { передвиборчої кампанії }\end{array}$ & 3,48 & 13 \\
\hline Обговорювати політичні події в сім’ї & 3,37 & 14,5 \\
\hline $\begin{array}{l}\text { Організувати збирання речей для постраждалих } \\
\text { від стихійного лиха }\end{array}$ & 3,37 & 14,5 \\
\hline $\begin{array}{l}\text { Прагнути переконати друзів у правильності своїх } \\
\text { ідеологічних поглядів }\end{array}$ & 3,36 & 16 \\
\hline
\end{tabular}


Продовження таблиияі

\begin{tabular}{|l|c|c|}
\hline $\begin{array}{l}\text { Активно виступати проти порушення Декларації } \\
\text { про права людини }\end{array}$ & 3,32 & 17,5 \\
\hline $\begin{array}{l}\text { Постійно обговорювати політичні реалії } \\
\text { зі знайомими людьми }\end{array}$ & 3,32 & 17,5 \\
\hline Постійно читати статті на політичні теми & 3,30 & 19,5 \\
\hline Завжди голосувати на виборах & 3,30 & 19,5 \\
\hline $\begin{array}{l}\text { Читати додаткову літературу для поглиблення } \\
\text { політичної компетентності }\end{array}$ & 3,26 & 21 \\
\hline $\begin{array}{l}\text { У повсякденному житті керуватися цінностями } \\
\text { європейської демократії }\end{array}$ & 3,09 & 22 \\
\hline $\begin{array}{l}\text { Виконувати доручення, пов'язані з діяльністю } \\
\text { певної політичної сили }\end{array}$ & 3,04 & 23 \\
\hline
\end{tabular}

Структурно-функціональний аналіз активної соціальної поведінки показує, що на перший план виходять дії, що реалізуються в груповій взаємодії. Це участь у громадських заходах та акціях, електоральні дії, вступ до партій та виконання доручень певної політичної сили; обговорення подій із сім'єю, друзями та знайомими; організація допомоги вразливим верствам населення. Такі діяння, як керування в житті цінностями демократії, відстежування політичних подій, а також читання статей на політичні теми, відходять в ієрархії дій на другий план. Оскільки соціальній поведінці властиві групові закономірності, для іiі активізації необхідні комунікативна та рольова компетентність та опанування основних поведінкових патернів соціально-політичної поведінки. Ситуативна схильність до спостереження, пасивність, очікування активності насамперед від інших людей, що було виявлено в ході дослідження, пояснюється, на нашу думку, не браком мотивації, а наявністю в молоді інших мотивів, які стримують їі активність.

Одним із фундаментальних чинників поведінкових виявів особистості є ï здатність до саморегуляції в процесі самоздійснення. Саморегуляція та саморозвиток, за М. Й. Боришевським, - це складне структурно-функціональне системне утворення, що охоплює такі важливі компоненти, як визначення мети, пошук засобів та способів ії досягнення, співвіднесення уявлень про себе 3 власними можливостями та вимогами мети, аналіз наявної ситуації, а також прогноз ії можливих результатів та наслідків власних дій і вчинків для себе й оточення [2]. Соціально-психологічні дослідження свідчать, що людьми рухають спонукання чинити відповідно до найбільш позитивних аспектів їхніх власних переконань, цінностей та уявлень про себе [13]. Саморегуляція здійснюється на основі моделювання предмета діяльності (Г. О. Балл, В. К. Вілюнас, В. О. Татенко), який має для особистості суб'єктивну цінність у вигляді образу бажаного майбутнього та визначенні доцільності та послідовності політичних дій $[1 ; 11]$. Компонентами моделі $є$ оцінка ситуації, визначення мети активної соціальної поведінки, іï осо- 
бистісного смислу та мотивації для учасника, здійснення вибору та планування ним соціально-політичних дій.

Спостерігаючи за іншими, ідентифікуючись із іншими, “приміряючи" на себе їхні ролі, взаємодіючи з ними, молода людина пізнає власну рольову ідентичність. 3'ясовано, що в процесі моделювання соціальної поведінки нею можуть бути опановані нові моделі соціальної поведінки та ролі, можуть бути засвоєні або вдосконалені нові, не властиві їй раніше моделі політичної поведінки, такі як "громадянин України”, “член суспільства”, “активіст”, “патріот”, “частина соціуму” та "соціально адаптована людина". Ранг цих соціальних ролей у рольовій ієрархії особистості підвищився після проведення тренінгу [7].

Висновки. Особистісно-рольове моделювання можна розглядати як проектування оптимальних послідовних дій у певній ситуації взаємодії, визначення необхідних засобів досягнення мети і можливих наслідків дій. Під час тренінгу з'являється можливість моделювати активну соціальну поведінку в безпечних умовах та здійснювати психологічний супровід діяння в складних проблемних ситуаціях з проблемної позиції, що передбачає розв'язання проблеми або зменшення ііі “травматичності”. Залучення молодих людей у політичний контекст відповідає кінцевій меті активної соціальної поведінки як здійснення суспільно корисних дій. Активна соціальна поведінка реалізується в діях і вчинках, які $є$ складниками рольових моделей поведінки групи, здійснюється в груповій взаємодії з участю однодумців, соратників.

Отже, особистісно-рольове моделювання активної соціальної поведінки дає змогу засвоювати і відтворювати моделі лояльної поведінки, здійснювати вибір дій та діянь. Психологічні технології особистіснорольового моделювання і практичні емпіричні напрацювання можуть бути використані для психологічного супроводу і формування активної соціальної поведінки молодих людей у процесі політичної участі.

\section{Лimepamypa}

1. Балл Г. А. Психология в рациогуманистической перспективе: избранные работы / Г. А. Балл. - Киев : Основа, 2006. -401 с.

2. Борышевский М. И. Развитие саморегуляции поведения школьников : дис. в форме научн. доклада д-ра психол. наук / Борышевский Мирослав Йосифович. - Киев, 1992. - 77 с.

3. Горностай П. П. Личность и роль: Ролевой подход в социальной психологии личности / П. П. Горностай. - Киев : Интерпресс ЛТД, 2007. - 312 с.

4. Гриффин Э. Коммуникации: теории и практики / Э. Гриффин. - Харьков : Гуманитар. центр, 2015. - $686 \mathrm{c.}$

5. Жадан I. B. Соціальне научання як механізм політичної соціалізації молоді в процесі модернізації освіти / І.В.Жадан // Наукові студії із соціальної та політичної психології : зб. статей / Нац. акад. пед. наук України, Ін-т соц. та політ. психології. - Київ : Міленіум, 2008. Вип. 19(22). - С. 231-238. 
6. Коробанова О. Л. Рольові аспекти групової взаємодії в умовах сучасності [Електронний ресурс] / О. Л. Коробанова // Особистість в умовах кризових викликів сучасності : матеріали методол. семінару НАПН України (24 берез. 2016 р.). - Київ, 2016.- Режим доступу : http://lib.iitta.gov.ua/704987/.

7. Коробанова О.Л. Ціннісно-рольові детермінанти мотивації політичної участі / О. Л. Коробанова // Психологічні перспективи. Спец. вип. "Психологія професійної діяльності працівників соціальної сфери”. - Київ : Золоті ворота, 2012. - С. 153-160.

8. Крылов В. Ю. Методологические и теоретические проблемы математической психологии / В. Ю. Крылов. - Москва : Янус-К, 2000. - 376 с.

9. Максименко С. Д. Психологія життєвої сили особистості / С. Д. Максименко // Медична психологія: здобутки, розвиток та перспективи : матеріали IV міжнар. наук.-практ. конф. 22-24 жовт. 2015 р. - Київ, 2015. C. 3-9.

10. Мелибруда Е. Я - ты - мы. Психологические возможности улучшения общения / Ежи Мелибруда. - Москва : Прогресс, 1986. - 256 с.

11. Основи психології: Підручник / за заг. ред. О. В. Киричука, В. А. Роменця, В. О. Татенка. - 2-ге вид. - Київ : Либідь, 1995. - 632 с.

12. Парсонс Т. О структуре социального действия / Т. Парсонс, В. Чеснокова. Москва : Академ. Проект, 2000. - 800 с.

13. РоссЛ. Человек и ситуация: Перспективы социальной психологии / Л. Росс, Р. Нисбет ; пер. с англ. В. В. Румынского ; под ред. Е. Н. Емельянова, В. С. Магуна. - Москва : Аспект Пресс, 1999. - 429 с.

\section{References}

1. Ball, G. A. (2006). Psikhologiya $v$ ratsiogumanisticheskoy perspektive: izbrannyye raboty [Psychology in the ratio-humanistic perspective: selected works]. Kyiv: Osnova Publ. (rus).

2. Boryshevskiy, M. I. (1992). Razvitiye samoregulyatsii povedeniya shkolnikov [Development of self-regulation of the school-children behavior]. D. Sc. Thesis, Kiev, Ukraine (rus).

3. Gornostay, P. P. (2007). Lichnost $i$ rol: Rolevoy podkhod $v$ sotsialnoy psikhologii lichnosti [A person and a role: Role approach in the social psychology of a person]. Kyiv: Interpress LTD Publ. (rus).

4. Griffin, E. (2015). Kommunikatsii: teorii i praktiki [Communications: theories and practices]. Harkov: Gumanitarnyy tsentr Publ. (rus).

5. Zhadan, I. V. (2008). Sotsialne nauchannia yak mekhanizm politychnoi sotsializatsii molodi $\mathrm{v}$ protsesi modernizatsii osvity [Social education as a of youth mechanism political socialisation in the process of education modernization]. Naukovi studii iz sotsialnoi ta politychnoi psykholohii [Scientific Studies of Social and Political Psychology], 19(22), 231-238 (ukr).

6. Korobanova, O. L. (2016). Rolovi aspekty hrupovoi vzaiemodii v umovakh suchasnosti [Role aspects of group interaction under contemporary conditions (March 24, 2015); Proceedings from a person under conditions of crysis challenges of modernity: materials of methodology seminar of Ukrainian NAPS]. Kyiv, pp. 306 - 315, http://lib.iitta.gov.ua/704987/ (ukr).

7. Korobanova, O. L. (2012). Tsinnisno-rolovi determinanty motyvatsii politychnoi uchasti [Value-role determinants of political participation motivation]. Psykho- 
lohichni perspektyvy: Spetsialnyi vypusk "Psykholohiia profesiinoi diialnosti pratsivnykiv sotsialnoi sfery" [Psychological prospects: Special edition "The psychology of professional activity of social workers"]. Kyiv: Zoloti vorota Publ. (ukr).

8. Krylov, V. Yu. (2000). Metodologicheskiye i teoreticheskiye problemy matematicheskoy psikhologii [Methodological and theoretical problems of mathematical psychology]. Moscow: Yanus-K Publ. (rus).

9. Maksymenko, S. D. (2015). Psykholohiia zhyttievoi syly osobystosti [The psychology of the living strength of a person. Medychna psykholohiia: zdobutky rozvytok ta perspektyvy [Medical psychology: achievements, development and perspectives: Proceedings from 4th International Scientific-Practical Conference]. Kyiv, pp. 3 - 9 (ukr).

10. Melibruda, Ye. (1986). Ya-ty-my. Psikhologicheskiye vozmozhnosti uluchsheniya obscheniya [Me - you - us. Psychological opportunities of the improvement of communication]. Moscow: Progress Publ. (rus).

11. Kyrychuk, O. V., Romenets, V. A., \& Tatenko, V. O. (Eds.). (1995). Osnovy psykholohii [The basics of psychology]. 2nd ed. Kyiv: Lybid Publ. (ukr).

12. Parsons, T. (2000). O strukture sotsialnogo deystviya [On the structure of social action]. V. Chesnokova (Ed.). Moscow: Akademicheskiy proekt Publ. (rus).

13. Ross, L., Nisbet, R. (1999). Chelovek $i$ situatsiya: Perspektivy sotsialnoy psikhologii [The man and the situation: Perspektives of social psychology]. Transl. by V. V. Rumynsky, E. N. Emelyanov \& B. C. Magun (Eds.). Moscow: Aspekt Press Publ. (rus).

\section{Korobanova O. L. Personal-and-Role Modeling of Active Social Behavior by Youth}

The personal-and-role modeling is rationalized and conceptualized as a phenomenon of role interaction, which implies in choosing and mastering the structural and functional "canvas" of actions and planning for further interaction. It is pointed out the importance of self-regulation of the personality and its subjective properties in the youth's active social behavior, which is based on the personal-androle modeling of social and interpersonal roles ability related to the role of a citizen. Personal-and-role modeling is considered as a resource for the activation of social behavior of young people, as it is assigned by the role of psychological mechanism for the development of loyal and successful roles as ways of action in various situations of social interaction. Attention is drawn to the fact that psychological technologies of personal-and-role modeling and practical empirical work can be used in psychological support and for the formation of active social behavior of young people in the process of political participation. In case of civic activity approach through the modeling point of view, the emphasis is placed on the formation of internal personal determinants, which predetermine behavior that allows the viewer to review and to impove still used stimulators of activity of young people as members of civil society.

Key words: active social behavior, political actions, role interaction, group interaction, modeling of role behavior, personal-and-role modeling.

(C) Коробанова О. Л. 
